\title{
CONFLICTOLOGICAL COMPETENCE OF FUTURE SPECIALIST AS THE DEVELOPMENT FACTOR OF SANOGENIC POTENTIAL
}

\author{
Ganna Polishchuk \\ PhD, Assistant Professor, Vladimir Vinnichenko Central Ukrainian \\ State Pedagogical University, Ukraine \\ e-mail: lopotova@ukr.net, orcid.org/0000-0002-9547-4959 \\ Angela Demchenko \\ PhD, Assistant Professor, Cherkasy Medical Academy, Ukraine \\ e-mail: dem4enkoav@gmail.com,orcid.org/0000-0001-6189-5264
}

\section{Hameni Blaise}

Ph.D., Institute of Vocational Training for Development, Douala-Akwa, Cameroon e-mail: bhameni@yahoo.fr,orcid.org/0000-0002-9922-7947

\section{Summary}

The problem of future specialist conflictological competence formation as the development factor of sanogenic potential in the educational environment of a higher education institution is relevant and requires immediate theoretical solution. The article reveals the content of basic concepts such as "conflictological competence", "conflictological competences" of future specialists, offers approaches to the conflictological competence development as a factor of the sanogenic potential development in the educational environment of higher education institutions.

In this study "conflictological competence" is understood as a necessary part of future specialists' professional competence, which includes the art of individual work with personality, mastery of various "keys" of communication, special methods of organizing one's psyche, means of emotional stress and anxiety reduction with the aim to ensure one's own mental health potential. The formation of conflictological competence is based on the following main blocks: theoretical knowledge in the field of conflictology and psychology; mastery of technologies that prevent, manage, minimize destructive conflict forms; formation of sanogenic type of thinking, which includes reflexivity, creativity, and dynamism; possession of stress-resistance technologies in conflicts, absence of fear in conflicts; adherence to professional ethics in conflicts; a high level of personal culture, which ensures the level of future specialists' psychological health.

Keywords: conflict, knowledge, personality communicativeness, verbal conflict situations, educational activities, prevention of professional burnout.

\section{DOI https://doi.org/10.23856/3928}

\section{Introduction}

The modern stage of the Ukrainian society development is characterized by various conflicts in material, mental, industrial and interpersonal relations. Therefore, a significant role in the structure of future specialists' professional competence is played by conflictological competence, which requires not only thorough conflictological knowledge but also a constructive solution of professional conflictological situations, conflict prevention and well-timed diagnosis.

Crisis phenomena in society lead to professional and social conflict situations cause the demonstration of destructive forms of behavior and distorted attitude towards the personality and the world around them. Therefore, the problem of conflict solution and the maintenance of individual sanogenic potential remain in the focus of scientific attention. 
Recognition of conflict as an inevitable phenomenon of everyday life highlights the problem of specific norms and behavioral rules development in conflict situations, as well as the development of individual and personal qualities that contribute to the constructive solution of various problems and mental health maintenance.

The conflictological competence - the ability and willingness of specialists to interact effectively in conflict, focusing on mutually beneficial needs and interests of all parties to the conflict situation, as well as implementing collaborative strategy - has received considerable attention recently.

The search for new approaches to the future specialists' education should be aimed at the comprehensive development of the individual as the main subject of the modern pedagogical process. Therefore, the priority of higher education institutions is to educate the individual who masters the art of cognition, thinking and communication, organization of personal intellectual and physical work, interest in the creative application of professional knowledge, the art of living by the laws of morality, and the ability to self-realization and self-regulation in professional activity. The ability to build constructive relationships with others and effectively overcome conflict situations is an important indicator of human development.

The ways of behavior in conflict situations, which are characteristic for each individual, appear at all stages of human socialization, in the process of active mastery of socio-professional relations, integration into a broad system of interpersonal relationships. Conflictological competence presupposes the ability of future specialists to interact with others effectively, reach consensus, prevent, localize and solve problematic and conflict situations based on humanity, tolerance, responsibility, cooperation, which is the key to the maintenance of sanogenic potential and leads to prevention of professional burnout.

This study aims to present the results of numerous works on the development of future specialists' conflictological competence and improvement of their interpersonal interaction, which can contribute to a deeper understanding of psychological and pedagogical processes and phenomena, improvement of the psychological climate in the educational environment of higher education institutions and determining the impact of conflict competence on the development of their sanogenic potential and determination of conflictological competence influence on the development of their sanogenic potential.

To achieve this aim such following tasks were set:

1. To analyze the current state of future specialists' training to prevent and solve verbal conflict situations in professional activities.

2. To reveal the peculiarities of future specialists' conflictological competencies formation.

3 . To determine the role of future specialists' conflictological competence in the development of their sanogenic potential.

The process of future specialists' conflictological competencies formation in the educational environment of a higher education institution is complex, longstanding but relevant because education is an important stage in the professional development of the individual.

These questions concern many scientists, but specific socio-pedagogical actions, organizational mechanisms for their formation remain unresolved.

Psychological knowledge of the rules and features of conflict-free communication and behavior helps not only to build constructive interpersonal relationships, but also to apply the ability to reconstruct the conflict, turn it into a tool of management and positively affect the development of sanogenic potential of the individual. This also will help maintain mental health and prevent professional burnout.

At the current stage, when the professional life of each person permanently becomes more complicated and the personal one brings constant problems, the role of conflictological competence has increased dramatically. 
After all, the fate of a particular person, the whole team, and even society depends on the ability of a modern worker to use the achievements of conflictology in the professional activities, in order to prevent, regulate and constructively solve any conflict situations.

\section{Training of future specialists to prevent and solve verbal conflict situations in professional activities}

The strategic directions of the education organization in higher education institutions are to ensure the quality level of future specialists' education, competitive personnel, which is capable of continuous self-improvement and expansion of knowledge in accordance with the needs of modern society.

The generalization of scientists' opinions allows us to state that the peculiarity of the „professional training” concept is its focus on the profession by mastering a certain set of knowledge, skills, qualities and practical experience, which are necessary for the successful solution of professional tasks. In the context of this study, the significant meaning belongs to conflictological component of future specialists' professional training, more precisely, preparation for the prevention and solution of verbal conflict situations in professional activities.

Scientists agree that the main purpose of conflict management is to prevent destructive conflicts and promote the adequate solution of constructive ones aimed at maintaining the sanogenic potential of future specialists. The term "prevention" usually has several meanings: 1) not to allow, to avoid in advance something unpleasant, undesirable; 2) to eliminate threatening things in advance, to prevent the implementation of something; 3) to withdraw in advance, to eliminate, to prevent danger; 4) to please, to flatter, to seek support and patronage; 5) to get, buy, find someone or something. Based on this, ,conflict prevention” is defined as an activity aimed at anticipating and preventing a conflict situation.

Nowadays, there is no clear distinction between the concepts of "conflict prevention", "conflict avoidance", and these concepts are often used as synonyms. Thus, the term "conflict prevention" is interpreted by scientists as: the organization of life of the subjects of social interaction, aimed at conflict prevention or minimization of its occurrence likelihood (Maksudov, 2009); recognition, elimination or attenuation of conflict factors in advance and thus limited possibilities of their occurrence or destructive development in the future (Ishmuratov, 1996); a type of management activity that consists in the early elimination or weakening of conflict factors and thus limited possibilities of their occurrence or destructive solution in the future. It is the organization of life of the subjects of social interaction, which eliminates or minimizes the likelihood of conflicts between them (Ratnykov, 2001).

According to these interpretations, effective prevention can avoid even the slightest negative consequences that may arise as a result of a conflict that has been solved constructively.

Regarding the phenomenon of "avoidance", researchers define it as: the organization of interaction and human cooperation, which eliminates or minimizes the possibility of conflicts between them; the activities of the subjects of interaction (or one of them), as well as third parties (intermediaries) to eliminate the objective and subjective causes of the impending conflict (Trus, Shubyna, 1999); the activities of individuals to eliminate the objective or subjective causes of the impending conflict, the solution of conflicts with non-conflict means (Romanova, 2014); one of the specific manifestations of human ability to generalize available theoretical and empirical data and on this basis to anticipate, predict the future, thus extending the field of the known to the unknown (Hryshyna, 2008); the type of activity of the subject of management, aimed at conflict prevention (Zinchyna, 2007). Thus, conflict avoidance requires 
the ability to manage the process of conflict solution until the conflict situation escalates into open confrontation.

Conflictological competence allows you to find patterns of conflict origin and development to eliminate it or contribute to its constructive solution; learn to critically analyze one's own capabilities and opportunities; master the technologies of conflict prevention, forecasting and constructive solution, which requires knowledge of ways for analyzing the situation (Ishmuratov, 1996). The leading role of conflict essential characteristics is played by knowledge, which is the basis for preventing the actions of conflicting persons, the formation of skills to manage the conflict and to act as a third party. Conflictological competence includes the ability to predict the future conflict situation, constructively change the conflict situation and use the conflict to achieve the goal, taking into account the interests of the other party.

The concept of conflictological competence implies, first of all, the ability of a specialist to understand and analyze, as well as to predict possible conflict situations, based on a system of relevant knowledge. At the same time, conflictological competence implies the presence of a significant practical component, i. e. skills and abilities to work in the field of conflict phenomena or situations, namely the applied usage of conflictological, psychological and pedagogical knowledge on conflict management strategies, which allows the specialist to solve the conflict situation in real life and professional activity, taking into account the interests of all parties involved and implementing a collaborative strategy.

Based on the abovementioned statements, we define the process of future specialists' training to prevent and solve verbal and conflict situations in professional activities as a kind of specific activity carried out at the global, local, individual levels within their competence, based on the principles of democracy, humanism, scientific validity, aimed at taking precautionary measures to predict and prevent the occurrence of conflict factors, conditions, causes and behavior in the professional sphere. Thus, the process of prevention and solution of verbal conflict situations in professional activities can be considered as cognitive (epistemological aspect) and transforming (praxeological aspect) activities that require the appropriate level of conflictological training, which presents the subject of our further reflection.

It can be stated that the process of future specialists' training to prevent and solve verbal conflict situations in professional activities is a cognitive-regulatory substructure of personality professionalism, a dynamic personal accomplishment, characterized by knowledge of the conflict, the possession of a wide range of behavioral conflict strategies, emotional self-direction and significant personal qualities. A specialist with a high level of training can go beyond the conflict situation, see the causes of the conflict, and take into account all aspects of the conflict situation while maintaining sanogenic potential.

In this study, the professional training of future specialists to prevent and solve verbal conflict situations is considered as a specific socio-cultural institution, through which the transmission of specialized social and cultural experience gained by society is carried out. New information technologies related to the formation and operation of electronic libraries, databases and knowledge, communication and telecommunications systems, the use of multimedia and geographic information systems have been emerging.

The analysis of psychological and pedagogical literature suggests that the future specialists' training to prevent and solve verbal conflict situations in professional activities involves: 1) the focus of the future specialists' personality on the successful implementation of anti-conflict activities, which in its essence is constructive, non-violent, creative, correct, tolerant and humane; 2) the theoretical readiness of the future specialist to carry out anti-conflict activity, which is based on a conscious assessment of psychological, pedagogical and conflict knowledge 
system; 3 ) the presence of personally and professionally significant qualities: affection for the future professional activity, responsibility, endurance, balance, empathy, etc.; 4) practical mastery of a set of conflictological skills, which ensures successful practical anti-conflict activities of the future specialist; 5) the development of skills to diagnose one's own proneness to conflict based on analysis, self-analysis, self-assessment, reflection on one's own behavior, actions, communication, relationships with the surroundings and correction of one's own activities, as well as anticipation of conflict situation, its diagnosis, the definition of methods and ways to solve conflict and prevent it (Ratnykov, 2001).

Analyzing future specialists' training to prevent and solve verbal conflict situations in professional activities, we focus on personal qualities, including humanity, adherence to principles, objectivity, etc. In this context, in our opinion, the formation of conflictological competencies in future specialists is the issue of high priority.

\section{Formation of future specialists' conflictological competencies}

Education plays an important role in the moral, economic and social development of society, especially in the process of its informatization and globalization.

The most important values of modern civilization and information society based on knowledge are learning and human competencies.

The process of future specialists' conflictological competencies formation is complex, longstanding but relevant because studying in a higher education institution is an important stage in the professional development of the individual. These questions concern many scientists, but specific socio-pedagogical actions, organizational and managerial mechanisms for their formation remain unresolved.

A successful specialist must have high competence and master a variety of competencies. The competence (from the Latin compete - to seek, answer, approach) is the range of powers granted by law, statute or other act to a particular body or official; knowledge and experience in a particular field (Slipushko, Yaremenko, 2006: 613). Competence is a good knowledge of something; the range of powers of any organization, institution or person (Trus, Shubyna, 1999: 874).

Accordingly, the authors have identified the following components important for the future specialist:

- knowledge necessary for humanistic communication;

- skills and abilities necessary for the successful solution of conflict situations;

- personal qualities;

- general culture, necessary for the formation of a humanistic worldview, the definition of spiritual values, moral and ethical principles of the individual;

- motivation of professional activity.

In our opinion, for the formation of future specialists' conflictological competencies in conflict management, it is necessary, first of all, to ensure the development of value orientations of humanistic communication and communicative qualities of future specialists in solving professional tasks.

The development of value orientations in the learning process is determined, on the one hand, by personal characteristics, awareness of personal interests and values, and, on the other hand, by social factors. The general mechanism of the development of the value is based on the dialogical style of communication. Such a mechanism acts as a process of knowledge transfer and acceptance, which has a semantic load. Empathy, respect for the individual and constructive criticism are included in the value orientations of future specialists' humanistic communication. 
Empathy is the comprehension of the emotional state of other people through involvement, penetration into their subjective world. Empathy is based on the ability to correctly imagine what is happening inside other people, what they experience and aspire, how they perceive and evaluate themselves and the world around them. The ability to look at people and perceive different events through their eyes is extremely important for understanding others.

Respect for the individual is an unconditional and invaluable acceptance of a communication partner. It is expressed by its recognition as the only value of the primary order, in relation to which the secondary values are determined.

Constructive criticism is manifested in the ability to independently defend one's own beliefs and find answers to objections; in the ability to analyze information, opinion for assessment and verification. The content of criticality includes not only "assessment", but also the ability of dialectical thinking: the ability to scientifically use scientific methods, principles and rules of logic (argumentation, proof, refutation).

Thus, the value orientations of humanistic conflict-free communication of future specialists are empathy, respect for the partner and constructive criticism.

The continuation of the conflict competence formation is entrusted to the higher school, because the practice shows that higher school graduates are not ready for conflict activity in a professional environment, which is expressed in insufficient development of professionally important qualities that provide guidance in a difficult situation during professional interaction, negative emotional states management, the importance of the conflict object assessment, the impact on the opponent, in order to prevent or solve the conflict. To eliminate such incompetence of students in conflict situations, it is necessary, first of all, to build the educational process so that there is no break between theory and practice. Therefore, during the educational process, great attention should be paid to conducting special psychological seminars, courses using various active forms of learning: business games, psychological workshops, trainings, etc. (Romanova, 2014). It is possible to promote the formation of qualified specialists in the field of conflict solution in the process of training sessions aimed at mastering the knowledge of conflicts, ways to prevent and solve them, as well as the formation of appropriate skills in the analysis of real conflict situations (Antonov, 2005).

\section{The role of future specialists' conflictological competence in the development of their sanogenic potential}

The concept of conflictological competence implies the ability of a specialist to understand and analyze, as well as predict possible conflict situations, based on a system of relevant knowledge. At the same time, conflictological competence implies the presence of a significant practical component, i. e. skills and abilities to work in the field of conflict phenomena or situations, namely the practical application of conflictological, psychological and pedagogical knowledge of behavioral strategies in conflict situations, which allows the specialist to solve the conflict situation in real life and professional activity, taking into account the interests of all parties involved and implementing a collaborative strategy.

The competence of the future specialist in solving conflicts is an important guarantee of effective and efficient work, especially if the specialist's work is related to direct communication with people.

The shortest way to maintain and strengthen professional health, the best psychological protection, in our opinion, is the mastery of the sanogenic type of thinking by future specialists. In order to be able to successfully adapt to new living conditions, solve conflicts harmoniously and 
effectively, interact in a specific environment, the specialists need to acquire appropriate adaptive thinking and behavior, be able to maintain their health and be environmentally friendly for others.

Since the prospects of creating a safe world for health remain unattainable, the urgent task of psychology is to optimize the practical assistance of the individuals in the development of their sanogenic potential - the ability to create a meaningful basis for health-developing (sanogenic) life choices. The sanogenic potential of an individual is the psychological basis of human vitality - the ability to manage the health resources, the capability not just to survive, but to live a full, satisfying life, which is a condition for sanogenic type of thinking formation.

The sanogenic potential of a person is understood as the psychoenergetic potential of an individual, which was formed as a derivative of his inner world richness, the breadth of social and spiritual spaces, experience gaining, achievements of his own well-being. It directly affects mental and professional health, longevity, as well as the tools that help to support it (Slipushko, Yaremenko, 2006: 867). The sanogenic potential of an individual is a phenomenon of his full functioning, which is manifested in the ability of a person to solve life problems in such ways that develop his viability.

The most systematically and deeply the problem of sanogenic thinking was developed by Yurii Orlov, who believes that the main role of this type of thinking is to create conditions for achieving goals of self-improvement, harmony of traits, agreement with oneself and others, getting rid of bad habits, managing one's emotions and controlling one's needs (Orlov, 2006). Such a way of thinking reduces internal conflict and tension, prevents diseases and strengthens health. In contrast to pathogenic, sanogenic thinking contributes to the recovery of the psyche and the elimination of outdated images and complexes, removes difficulties in communication, gives success in activities and life and fills the body with healing potential.

The pathogenic thinking is the opposite in meaning to sanogenic. It contains such traits that contribute to mental stress, the formation of reactions and stereotypes of behavior that involves a person in conflict situations and results in deterioration of mental and physical health, which can lead even to professional burnout. Features of pathogenic thinking are: detachment from reality; lack of reflection, tendency to retain resentment, jealousy, shame and fear; tendency to live by memories, to be engaged in self-chastising; constant expectation of negative events, programming oneself for the negative; tendency to hide one's true face under a mask, inability and unwillingness to be oneself; inability to effectively use one's own intellectual abilities, etc.

Yurii Orlov identifies the following manifestations of pathogenic thinking: pathogenic psychological defense (aggression, fear), pathogenic nature of emotions (resentment, guilt, shame), the paradigm of forced control (revenge, threats) (Orlov, 2006). A specialist with a pathogenic type of thinking is of little use in the professional sphere because emotions take control over the actions.

Losing self-control, one can use such actions and techniques that reduce the effectiveness of professional activities and contribute to the emergence of nervous disorders. A specialist with a predominance of sanogenic type of thinking, on the contrary, is able to focus on the positive experience, free from anger, open to friendly relations with colleagues; he can forgive offenses and is able to live in harmony with others and himself.

A specialist with a sanogenic type of thinking has the following features: a fairly high level of general worldview and internal culture; ability to reflect on the background of deep inner harmony; high degree of focus and concentration on the objects of reflection; knowledge of the specific mental states nature, which allows him not to take offense at the offender, to cope with frustration in a situation of failure, to correctly understand the emotional reaction of a communication partner (guilt, shame, envy) and help him get rid of such states; ability to 
stop thinking in time and shift his attention to positively colored images; absence of expecting unpleasant situations, failures in the future (Orlov, 2006).

Favorable conditions for the correction of the type of thinking are the training stage in a higher education institution. After all, this period coincides with the final stage of becoming a specialist. The integration of a specialist into professional activity amends his worldview and type of thinking.

The peculiarities of sanogenic potential self-regulation in difficult living conditions mean that the specialist should:

- learn to find time for self-development and notice every, even small step in one's own development. Feel the joy of each successful step and experience it. Both learning and self-learning are more successful if they bring joy.

- be able to perceive events philosophically, see different situations and himself in them in a broader perspective, from the side.

- be able to perceive events with irony, appreciate and develop a sense of humor. According to the research of the English psychotherapist Robert Holden, laughter has a multifaceted positive effect on the human psyche and body. It stimulates all the most important organs, like a therapeutic massage. One minute of laughter is equivalent to 45 minutes of stress-relieving exercise. Laughter lowers blood pressure, improves blood circulation, facilitates breathing, helps remove stress hormones from the body, and strengthens the immune system. It makes a person less susceptible to pain.

- keep the most valuable ability to feel pleasure even from today's small joy. One should not stay in past memories for long. When working for the future, one does not have to think about it all the time. There can be no future without the present. The ability to evaluate the pleasure of the present is invaluable.

- not lose optimism and positive perception of events. Strengthening our mental strength, we focus on something promising, on the ways of solving problems and overcoming difficulties. A positive attitude is also needed in interpersonal relationships. It is necessary to try to see merits in people and to pay more attention to them, instead of noticing the downsides each person has. The advice how to treat problems has come to us from the depths of the centuries. All problems are divided into two types: those that can be solved and those you can do nothing with them. The first ones should be solved without worrying about it. The others should not be solved at all, and that is why should not be worried about.

- not worry about troubles that have not occurred yet, because they may not occur at all.

The formation of such skills is the key to maintaining professional longevity for specialists and a precautionary measure of professional burnout.

Positive thinking, as a way of mental self-regulation, is characterized by the fact that a person consciously controls thoughts, emotions and does not succumb to negative thoughts and emotions. At the same time, a person believes in himself, believes in ultimate success and remains an optimist under any circumstances. As a rule, it is typical of a positive „self-concept” of personality and to some extent represents a habit.

Mastering positive thinking helps a person realize his potential and pave the path of life. It gives a person who persistently and passionately masters it:

- faith in one's own strength;

- achieving success in any business;

- successful overcoming of obstacles, failures and crises;

- more „calm” adaptation to changes in life;

- optimism, self-control, benevolence and life satisfaction; 
- good relations with people;

- healthy lifestyle.

Moreover, positive thinking is invariant. It can be used by any person in any sphere of life.

An important place in the formation of optimistic personality traits is occupied by the system „Smart World” that was developed by Oleksandr Sviiash. This system is a positive philosophy of life, according to which:

1. All people are born for joy and spiritual development.

2. All people have potentially unlimited opportunities to create their own life. But, in most cases, we use it unsatisfactory.

3. The situation in which we find ourselves is the best situation we managed to create for ourselves today. This is only the result of our efforts, so we need to start enjoying it now.

4. There is no one but us who creates problems for us. We are responsible for everything we have in our lives (other people are responsible for their own lives).

5. All people can change only their situation for the better at any time. To do this, we only need to realize how we created problems and change our attitude to this situation.

6. Our consciousness in the form of explicit and implicit thoughts and attitudes determines our actions, and our actions create the situation which we are dissatisfied with. So, we will change our actions and our reality by changing our thoughts.

The smart way helps those people who believe in themselves and make efforts to change their situation for the better and gives a real tool to manage their lives, happiness and success.

Taking into account the abovementioned point of view, it is possible to state that the period of professional training is favorable for the type of thinking correction. Because mastering the profession coincides with the final age stage of personality formation. An acquaintance of students with the basics of professional activity, their first steps in it make adjustments in the worldview of the future specialist, in his thinking, which will ensure a reliable moral and ethical functioning of the individual. Sanogenic thinking is one of the effective means of solving psycho-traumatic problems, which is based on conscious analysis and experience, conscious reflection of one's emotions and emotional (stressful) factors and a high degree of one's own responsibility for the results of one's activities.

\section{Conclusions}

Summarizing the abovementioned, it can be stated that the concept of conflictological competence implies the ability of a specialist to understand and analyze, as well as to predict possible conflict situations, based on a system of relevant knowledge. At the same time, conflictological competence implies the presence of a significant practical component, i. e. skills and abilities to work in the field of conflictological phenomena or situations, namely the practical application of conflictological, psychological and pedagogical knowledge of behavioral strategies in conflict situations. This allows the specialist to solve the conflict situation in real life and professional activity, taking into account the interests of all parties involved, implementing a collaborative strategy and saving the sanogenic potential. The competence of the future specialist in solving conflicts is an important guarantee of his effective and efficient activity, especially if his professional activity is connected with direct communication with people. The emphasis is placed on the importance of acquiring the ability to overcome conflicts and prevent their occurrence as a necessary quality of a specialist, whose activities are saturated with various conflict situations that arise in the process of communication. It is noted that conflictology studies do not receive enough attention in higher education institutions. It is emphasized that during 
the future specialists' training, specific attention should be paid to the acquisition of knowledge and skills to identify the causes of conflicts. It is noted that conflict prevention is a set of measures aimed at delaying or preventing its occurrence and reducing the destructive impact of the conflict on various aspects of the social system aimed at preserving the sanogenic potential.

It is determined that the conflictological competence of future specialists is a structured system of knowledge about conflicts, the ability to manage them and the experience that determines the success of the regulation of activities and behavior. The preventive component is aimed at relieving tension in communication between specialists in the early stages and preventing the development of conflict interaction. Prevention represents the organization of life of the subjects of social interaction (team members), which eliminates or minimizes the likelihood of conflict occurrence. A specialist trained to prevent conflict should be observant and notice people who may be the cause and organizers of interpersonal conflicts, conflicts in the team and conflicts between teams.

In modern society, people are constantly exposed to various conflictogenic influences of the environment. Sanogenic thinking will help to develop control over emotions, work on thoughts that can destroy the mental and physical health of the individual.

The person with sanogenic thinking differs from pathogenic-thinking personality by the ability to be the first one, who quickly returns to a state of harmony in a potential conflict situation without entering into emotional stress. This ability is acquired through mastering the skills of emotion control.

The period of professional training is favorable for the type of thinking correction. Because mastering the profession coincides with the final age stage of personality formation. Sanogenic thinking is one of the effective means of solving psycho-traumatic problems, which is based on conscious analysis and experience, conscious reflection of one's emotions and emotional (stressful) factors and a high degree of one's own responsibility for the results of one's activities.

The managerial elite can cause dynamic and qualitative changes in the functioning of the Ukrainian society now and in the future. This is possible under the condition of constant correction of the Ukrainian education system to modern world tendencies. The real needs of the Ukrainian strategic development need, first of all, a significant improvement in the quality of professional training. As proven by many well-known scientists, conflictogenity of modern society in general and any professional activity in particular, indicates the need for the formation of conflictological competence of competitive professionals. The prospects of the study are seen in the analysis of conflictological knowledge and skills application in professional activities acquired in the process of learning, which will identify the ways to organize independent work to increase the conflictological competence of future specialists, maintain their psychological health and avoid professional burnout.

\section{References}

Antonov H. V. (2005). Komponenty orhanizatsiino-pedahohichnoi diialnosti iz zapobihannia i podolannia konfliktiv u pedahohichnomu vyshchomu navchalnomu zakladi. [Spirituality of personality: methodology, theory and practice: collection of scientific papers]. Luhansk: SNU. [in Ukrainian]

Hryshyna N. V. (2008). Psykholohyia konflykta. [Psychology of conflict]. SPb. : Pyter. [in Russian]

Zinchyna O. B. (2007). Konfliktolohiia : navchalnyi posibnyk. [Conflictology: a guide]. Kharkiv : KhNAMH. [in Ukrainian] 
Ishmuratov A. T. (1996). Konflikt i zghoda: osnovy kohnityvnoi teorii konfliktiv. [Conflict and consent. Fundamentals of cognitive conflict theory]. Kyiv : Naukova dumka. [in Ukrainian] Maksudov R. R. (2009). Vosstanovytelnaia medyatsyia: ydeia y tekhnolohyia: Metod. rekomendatsyy. [Restorative mediation: idea and technology: Methodogical recommendations]. Moscow : Ynstytut prava y publychnoi polytyky. [in Russian]

Orlov Yu. M. (2006). Ozdoravlyvaiushchee (sanohennoe) mblshlenyia. [Healing (sanogenic) thinking Series: Behavior Management, Book 1]. Moscow : Slaidynh. [in Russia]

Romanova H. M. (2014). Teoriia i praktyka vprovadzhennia innovatsiinykh tekhnolohii navchannia u profesiinu pidhotovku kvalifikovanykh robitnykiv : monohrafia. [Theory and practice of introducing innovative learning technologies in training of specialists: monograph]. Kyiv : Polihrafservis. [in Ukrainian]

Ratnykov V. P. (2001). Konflyktolohyia : uchebnyk dlia vuzov. [Conflictology: a textbook for universities]. Moscow : YuNYTY-DANA. [in Russian]

Slipushko O. M., Yaremenko V. V. (2006). Novyi tlumachnyi slovnyk ukrainskoi movy. [New explanatory dictionary of the Ukrainian language. In 3 volumes. Vol. 1]. Kyiv: «AKONIT». [in Ukrainian]

Trus N.V., Shubyna T.H. (1999). Slovar ynostrannblkh slov y vblrazhenyi. [Dictionary offoreign words and expressions]. Mynsk: Sovremennbil lyterator. [in Belorussian] 